\title{
Ruminal degradation of dry matter, crude protein and fiber fraction of oilseed byproducts
}

\author{
Degradação ruminal da matéria seca, proteína bruta e fração \\ fibrosa de coprodutos de oleaginosas
}

\author{
Ana Paula da Silva Antunes ${ }^{1 *}$; Aureliano José Vieira Pires ${ }^{2}$; Fábio Andrade \\ Teixeira $^{2}$; Gleidson Giordano Pinto de Carvalho ${ }^{3}$; Marcelo Mendes Corrêa ${ }^{1}$; Flávio \\ Pinto Monção ${ }^{4}$; Leandro Sampaio Oliveira Ribeiro ${ }^{1}$; Daniel Lucas Santos Dias ${ }^{1}$; \\ Wéder Jânsen Barbosa Rocha ${ }^{1}$; Daniella Cangussú Tolentino ${ }^{1}$
}

\begin{abstract}
The objective was to evaluate the rumen degradability of dry matter, crude protein and fiber fraction of some oilseed byproducts. Oilseed byproducts evaluated were: Sunflower Meal, Cotton Cake and Castor Bean Cake. The rumen degradability test was performed following a split plot randomized complete block design with three treatments (plots) and seven incubation times (subplots) and six blocks (animals). The readily soluble fraction of the dry matter of sunflower meal was $35.0 \%$ higher than the same fraction of cotton cake and castor bean cake (mean $24.46 \%, \mathrm{P}<0.01$ ). The highest potential degradability of crude protein $(\mathrm{P}<0.01)$ was verified in castor bean cake $(96.90 \%, 5 \%$ rate of passage). Sunflower meal had the lowest insoluble fraction of the fiber fraction, $34.4 \%$, compared to cotton cake and castor bean cake, with $64.4 \%$ and $39.4 \%$, respectively $(\mathrm{P}<0.01)$. Sunflower meal had the highest fiber effective degradability (25.2\%). Sunflower meal presented better values of ruminal parameters of dry matter, crude protein and neutral detergent fiber in relation to the other byproducts.
\end{abstract}

Key words: Fermentation kinetics. Digestibility. Agroindustrial residues. Degradation rate.

\section{Resumo}

\begin{abstract}
Objetivou-se avaliar a degradabilidade ruminal da matéria seca, proteína bruta e fração fibrosa de alguns coprodutos de oleaginosas. Os coprodutos de oleaginosas avaliados foram: Farelo de Girassol, Torta de Algodão e Torta de Mamona. O ensaio de degradabilidade ruminal foi conduzido seguindo o delineamento em blocos casualizados em esquema de parcelas subdivididas com três tratamentos (parcelas) e sete tempos de incubações (subparcelas) e seis blocos (animais. A fração prontamente solúvel da matéria seca do farelo de girassol foi $35,0 \%$ superior em relação à mesma fração dos coprodutos torta de algodão e torta de mamona (média $24,46 \% ; P<0,01$ ). A maior degradabilidade potencial da proteína bruta $(P<0,01)$ foi verificada na torta de mamona $(96,90 \%$; taxa de passagem de 5\%). O farelo de girassol apresentou menor fração insolúvel potencialmente degradável da fração
\end{abstract}

\footnotetext{
1 Nutricionistas, Universidade Estadual do Sudoeste da Bahia, UESB, Itapetinga, BA, Brasil. E-mail: anapaula-antunes@hotmail. com; marcelozoonutri@hotmail.com; leosampaio-zoo@hotmail.com; dlsd_@hotmail.com; wederjb.rocha@yahoo.com.br; danycangussu@bol.com.br

2 Profs. Drs., UESB, Itapetinga, BA, Brasil. E-mail: aurelianojvp@yahoo.com.br; fteixeira@uesb.edu.br

3 Prof. Dr., Universidade Federal da Bahia, UFBA, Salvador, BA, Brasil. E-mail: gleidsongiordano@yahoo.com.br

4 Pós-Doutorando e Prof. Colaborador, Programa de Pós-Graduação em Zootecnia, Universidade Estadual de Montes Claros, UNIMONTES, Janaúba, MG, Brasil. E-mail: moncaomoncao@yahoo.com.br

* Author for correspondence
} 
fibrosa, 34,4\%, em relação à torta de algodão e torta de mamona que apresentaram média de $64,4 \%$ e $39,4 \%$, respectivamente $(P<0,01)$. O farelo de girassol apresentou maior degradabilidade efetiva da fibra $(25,2 \%)$. O farelo de girassol apresentou melhores valores dos parâmetros ruminais da matéria seca, proteína bruta e fibra em detergente neutro em relação aos demais coprodutos.

Palavras-chave: Cinética da fermentação. Digestibilidade. Resíduos agroindustriais. Taxa de degradação.

\section{Introduction}

Ruminant production in Brazil is based on the use of forage plants as one of the major sources of nutrients for animals (RIGUEIRA et al., 2018; SANTANA et al., 2019). However, forage production is not constant throughout the year, which makes it a limitation of animal production only on pasture forage (OLIVEIRA et al., 2014; SOUZA et al., 2015). Among the planning strategies to maintain milk and meat production throughout the year, we highlight the conservation (i.e. deferment, silage, hay) of the surplus of forages traditionally grown in each region, as well as the use of alternative food sources such as the byproducts of oilseeds produced in agroindustries (SOUZA et al., 2015; RIGUEIRA et al., 2018). The byproducts and coproducts generated in the production of biodiesel present potential to be used in the supplementation of ruminants due to the concentration of nutrients such as non-fiber carbohydrates, ether extract, crude protein and minerals (GOES et al., 2011). Sunflower (Helianthus annuus) meal, cotton (Gossypium spp.) cake and castor bean (Ricinus communis) cake are interesting oilseed byproducts for use in ruminant feed, but there is still little research on these nutrients. According to Abdalla et al. (2008), on average, more than $1500 \mathrm{~kg} / \mathrm{ha} /$ year of these byproducts are produced in Brazil. Castor bean cake is a byproduct with greater availability in the Northeast region of Brazil, which makes interesting the acquisition cost for cattle ranchers. However, the sunflower meal and cotton cake is produced in several regions of Brazil, which makes interesting research with these ingredients. The evaluation of the chemical composition associated with ruminal kinetic studies is fundamental in the balancing and formulation of diets for production animals. Among the methods of evaluating feed for ruminants, the in-situ technique has stood out because it is accurate and presents better economic viability than the in vivo techniques that are more accurate (NOCEK, 1988). In Brazil, studies are conducted with this technique to evaluate forages, agricultural residues and industrial byproducts in cattle feed (GOES et al., 2011; OLIVEIRA et al., 2014; MONÇÃO et al., 2014, 2016).

In this way, the objective of this study was to evaluate the ruminal degradability of dry matter, crude protein and fiber fraction of some byproducts of oilseeds with potential to be used in the ruminant diet.

\section{Material and Methods}

The techniques and procedures used in the present research complied within the norms of the National Council for Control of Animal Experimentation (CONCEA), and were approved by the Ethics Committee on Animal Use (CEUA) of the State University of Southwest of Bahia (protocol 128/2016).

The chemical analyses were carried out at the Forage and Pasture Laboratory of the State University of the Southwest of Bahia (UESB), Campus of Itapetinga, State of Bahia, while the in situ degradability test was carried out at the Bovinoculture Sector, UESB. The oilseed byproducts evaluated were Sunflower Meal (FG), Cotton Cake (TA) and Castor Bean Cake (TM). Ten samples of each byproduct were collected in the same industry from different batches. Samples were homogenized, pre-dried in a forced ventilation 
oven at $55^{\circ} \mathrm{C}$ for 72 hours, ground in a Wiley mill with a $1 \mathrm{~mm}$ sieve and analyzed for dry matter (DM; 934.01), mineral matter (ash, 942.05), ether extract (EE; 920.39), crude protein (CP; 978.04), as described by AOAC (1995). Neutral detergent fiber (NDF) and acid detergent fiber (FDA) were determined by the sequential method, according to procedures described by Robertson and Van Soest (1981) using the TECNAL ${ }^{\circledR}$ TE-149 fiber determiner (Piracicaba, SP, Brasil). Cellulose was solubilized in $72 \%$ sulfuric acid and lignin content was obtained as the difference (GOERING; VAN SOEST, 1970). The chemical composition of byproducts are listed in Table 1.

Table 1. Chemical composition of byproducts.

\begin{tabular}{lcccc}
\hline \multirow{2}{*}{ Items $\left(\mathrm{g} \mathrm{kg} \mathrm{DM}^{-1}\right)$} & \multicolumn{3}{c}{ Byproducts } & SEM \\
\cline { 2 - 4 } & Sunflower meal & Cotton cake & Castor bean cake \\
\hline Dry matter & 915 & 926 & 928 & 1,4 \\
Ash & 83 & 50 & 77 & 1 \\
Crude protein & 282 & 281 & 391 & 6 \\
Non-fiber carbohydrates & 356 & 232 & 239 & 10 \\
Ether extract & 26 & 41 & 15 & 0,8 \\
Neutral detergent fiber & 473 & 497 & 495 & 15,6 \\
Acid detergent fiber & 389 & 383 & 446 & 5,3 \\
Hemicellulose & 84 & 114 & 49 & 13,2 \\
Cellulose & 270 & 274 & 125 & 4,6 \\
Lignin & 106 & 106 & 245 & 6,8 \\
\hline
\end{tabular}

DM- Dry matter; SEM - Standard error of the mean.

For the evaluation of ruminal degradation kinetics of DM, CP and NDF, six adult male cattle weighing $280 \pm 30 \mathrm{~kg}$, castrated, crossbred (Nellore x Holstein), with ruminal cannulas were kept in a single paddock of Brachiaria brizantha cv. Marandu. The animals received a mixture of 1.0 $\mathrm{kg}$ each byproduct, divided equally in two meals, morning and afternoon. The in situ degradability technique was used with non-woven bags (weight 100), measuring $7.5 \times 15 \mathrm{~cm}$, with approximate porosity of $60 \mu \mathrm{m}$ according to Casali et al. (2009), with the number of samples following a ratio of 20 mg DM.cm ${ }^{-2}$ of bag surface area (NOCEK, 1988).

The bags were then placed in tulle bags measuring $20 \times 30 \mathrm{~cm}$ along with $100 \mathrm{~g}$ lead weights. The bags were tied with a nylon thread, with a free length of $1 \mathrm{~m}$ so that they had free movement in the solid and liquid phases of the rumen. The bags were then deposited in the ventral sac region of the rumen for $0,12,24,48,72,96$ and 120 hours (CASALI et al., 2009), with the end of the nylon thread remaining attached to the cannula. The bags are placed in reverse order, starting with the time of 120 hours. Afterwards, all the samples were collected and washed in ice water, aiming to stop ruminal fermentation. Samples for the 0-hour time were washed in running water together with the other samples. Subsequently, the samples were placed in oven at $55^{\circ} \mathrm{C}$ for 72 hours and after, cooled in desiccator and weighed.

The residues remaining in the non-woven bags collected in the rumen were analyzed for DM, CP and NDF contents according to the methodologies described. The percentage of degradation was 
calculated by the proportion of food remaining in the bags after ruminal incubation. The fiber NDF was analyzed according to the methods proposed by Robertson and Van Soest (1981) without the use of $\alpha$-amylase.

Data obtained were fit to a non-linear regression by the Gauss-Newton method (NETER et al., 1985), using SAS software (SAS, 2008), according to the equation proposed by (ØRSKOV; MCDONALD, 1979): $\mathrm{Y}=\mathrm{a}+\mathrm{b}\left(1-\mathrm{e}^{-\mathrm{ct}}\right)$, where: $\mathrm{Y}=$ accumulated degradation of the nutrient component analyzed after time $\mathrm{t} ; \mathrm{a}=$ degradation curve intercept when $\mathrm{t}=0$, which corresponds to the water soluble fraction of the nutrient component analyzed; $b=$ degradation potential of the water insoluble fraction of the nutrient component analyzed; $\mathrm{a}+\mathrm{b}=$ potential degradation of the nutrient component analyzed when time is not a limiting factor; $\mathrm{c}=$ degradation rate by fermentative action of $b ; t=$ incubation time.

After calculated, the coefficients $\mathrm{a}, \mathrm{b}$ and $\mathrm{c}$ were applied to the equation proposed by Ørskov and Mcdonald (1979): $\mathrm{ED}=\mathrm{a}+(\mathrm{bxc} / \mathrm{c}+\mathrm{k})$, where: $\mathrm{ED}=$ effective ruminal degradation of the nutrient component analyzed; $\mathrm{k}=$ rate of food passage. It was used rumen particle passage rates estimated at 2, 5 and $8 \% \mathrm{~h}^{-1}$, as suggested by AFRC (1993).

The degradability of NDF was estimated using the model of Mertens and Loften (1980): Rt = B $\mathrm{x}^{-\mathrm{ct}}+\mathrm{I}$, where $\mathrm{Rt}=$ fraction degraded at time $\mathrm{t}$; $\mathrm{B}=$ potentially degradable insoluble fraction and $\mathrm{I}=$ indigestible fraction. After the adjustments of the NDF degradation equation, fractions were standardized, as proposed by Waldo et al. (1972), using the equations: $\mathrm{Bp}=\mathrm{B} /(\mathrm{B}+\mathrm{I}) \times 100 ; \mathrm{Ip}=\mathrm{I} /$ $(\mathrm{B}+\mathrm{I}) \times 100$, where: $\mathrm{BP}=$ standardized potentially degradable fraction (\%); Ip = standardized indigestible fraction (\%); $\mathrm{B}=$ potentially degradable insoluble fraction and I = indigestible fraction. In the calculation of the effective degradability of NDF, the following model was used: $\mathrm{ED}=\mathrm{Bp} \times \mathrm{c} /(\mathrm{c}+\mathrm{k})$, where $B_{p}$ is the standardized potentially degradable fraction (\%).

The rumen degradability test was conducted following a split plot randomized complete block design with three treatments (plots) and seven incubation times (subplots) and six blocks (animals). The replicates were the six animals cannulated in the rumen and the treatments consisted of byproducts (FA, TA and TM). The different weights of the animals were the blocking factor. Data were tested for error normality, homogeneity of variances and additivity and, when not significant, they were subjected to analysis of variance using mixed models through the MIXED procedure of SAS 9.0 (SAS, 2008). The means when significant by the F-test were compared by Tukey's test. For all statistical procedures, $\alpha=0.05$ was used as the tolerable maximum limit for type III error.

\section{Results and Discussion}

There was a difference between the byproducts evaluated on the ruminal degradation parameters of the dry matter (DM). The sunflower meal had mean values $35.00 \%$ higher for the readily soluble fraction of DM (Fraction A) compared to cotton cake and castor bean cake, respectively (mean $24.46 \%$; Table 2). This was due to the higher concentration of non-fiber carbohydrates in this byproduct (NFC, 356 g.kg DM ${ }^{-1}$ ). NFCs are rapidly fermented in the rumen and used as a source of energy by ruminal microorganisms, especially when the NFCs is composed mostly of soluble carbohydrates such as sugars of up to six carbons (VAN SOEST, 1994). 
Table 2. Rumen degradability of dry matter of oilseed byproducts.

\begin{tabular}{lccccc}
\hline & \multicolumn{3}{c}{ Byproducts } & SEM & P-value \\
\cline { 2 - 4 } \multicolumn{1}{c}{ Items (\%) } & $\begin{array}{c}\text { Sunflower } \\
\text { meal }\end{array}$ & Cotton cake & $\begin{array}{c}\text { Castor bean } \\
\text { cake }\end{array}$ & SEM & \\
\hline Fraction A & $33.02 \mathrm{a}$ & $24.59 \mathrm{~b}$ & $24.33 \mathrm{~b}$ & 0.32 & $<0.01$ \\
Fraction B & $33.64 \mathrm{c}$ & $52.27 \mathrm{a}$ & $44.62 \mathrm{~b}$ & 0.41 & $<0.01$ \\
Degradation rate c, \%/hour & $0.14 \mathrm{a}$ & $0.03 \mathrm{~b}$ & $0.05 \mathrm{~b}$ & 0.01 & $<0.01$ \\
Potential Degradability & $66.67 \mathrm{c}$ & $76.86 \mathrm{a}$ & $68.96 \mathrm{~b}$ & 0.17 & $<0.01$ \\
Effective Degradability, 2\% & $62.47 \mathrm{a}$ & $56.49 \mathrm{~b}$ & $56.83 \mathrm{~b}$ & 0.23 & $<0.01$ \\
Effective Degradability, 5\% & $57.84 \mathrm{a}$ & $44.73 \mathrm{c}$ & $47.42 \mathrm{~b}$ & 0.39 & $<0.01$ \\
Effective Degradability, 8\% & $54.48 \mathrm{a}$ & $39.30 \mathrm{c}$ & $42.24 \mathrm{~b}$ & 0.46 & $<0.01$ \\
Undegradable fraction & $33.32 \mathrm{a}$ & $23.13 \mathrm{c}$ & $31.04 \mathrm{~b}$ & 0.17 & $<0.01$ \\
\hline
\end{tabular}

Means followed by different letters, in the same row, are significantly different by Tukey's test $(\mathrm{P}<0.05)$. SEM - Standard Error of the Mean. P - Probability.

However, it was verified that the cotton cake presented higher fraction $\mathrm{B}$ and potential degradability (PD) of DM compared to the other byproducts. Of the total cotton cake byproduct consumed by the animals, $76.86 \%$ presented degradation potential in the rumen, being this average 8 percentage units higher than the castor bean cake and 10.2 percentage units higher than the sunflower meal. The fraction $\mathrm{B}$ is related to the NDF content of the food, mainly the content of hemicellulose and cellulose, justifying the greater potential of degradation of the cotton cake in relation to the other byproducts. According to Fortaleza et al. (2009), linter, a fiber material that surrounds cottonseed, can raise the NDF content, justifying the NDF values of the cotton cake and, consequently, reducing rumen degradability. The lowest mean PD was observed in the sunflower cake $(66.67 \mathrm{~g} / \mathrm{kg} \mathrm{DM})$, due to the lower content of NDF (47.3\%) and fraction B. However, the degradation rate of fraction $B$ in sunflower meal was higher than the others, which increased the effectiveness of the degradation (ED) in all the passage rates $(2 \%, 5 \%$ and $8 \%)$. In high production animals, the rumen digesta passage rate varies from $5 \%$ to $8 \%$, but may reach up to $12 \%$, which is not interesting when increasing the synthesis of microbial protein, since the nutrients will have short time to exposure to ruminal microorganisms. Fortaleza et al. (2009) analyzed the ruminal degradation of some concentrate supplements used in bovine feed, and verified that the whole cottonseed and soybean meal presented PD of DM at $59.57 \%$ and $97.79 \%$, respectively. The observed values of PD of DM of the cotton cake was superior to the cottonseed and close to the soybean meal, which is a byproducts widely used as a source of protein for the animals. Goes et al. (2011) evaluated different byproducts of oilseeds and quantified $52.61 \%$ of ED ( $\mathrm{k}=5 \%$ /hour $)$ of soybean meal DM. In this study, considering the ED in the average rate of passage $(5 \%)$, the sunflower meal presented a value of $57.84 \%$, which was $29.3 \%$ and $22 \%$ higher than the cotton cake and castor bean cake, respectively. The highest mean values for sunflower meal occurred because the degradation rate of fraction $\mathrm{B}$ was higher in relation to the other byproducts and this influences the estimation of ED. Fortaleza et al. (2009) observed ED of DM of soybean meal in the order of $67.35 \%$, close to that verified in this study for sunflower meal. The lowest ED of DM was observed in the cotton cake byproduct for all rates of passage. This may be associated with the ether extract content, which according to Mir et al. (1984) and Goes et 
al. (2011), can clog the pores of the nylon bags and decrease degradation. This is because, during the grinding process, the hard shell of the kernel is partially pulverized by the mill and mixed with the fat of the food, making it difficult for particles to pass through the mesh of the sieve (MOREIRA et al., 2003). Fortaleza et al. (2009) observed this behavior in the cottonseed with $15.45 \%$ ether extract.

Due to the lower PD observed in sunflower meal, it was observed a larger undegradable fraction (UF, mean $33.32 \%$ ) of DM in relation to the other treatments. The cotton cake showed values of UF $30.58 \%$ lower than sunflower meal and $6.8 \%$ than castor bean cake (31.04\%). The factors that increase UF include the high content of lignin and other phenolic compounds (JUNG, 1989). Moreover, according to the same author, the formation of ester bonds between lignin and hemicellulose is one of the major obstacles to the ruminal microorganisms to degrade the cell wall of the plants, consequently affecting the utilization of the nutrients of the DM, causing an imbalance in the synchronization of protein and energy in the rumen. In this study, the lignin content was the same for sunflower meal and cotton cake, 106 g.kg DM ${ }^{-1}$. However, due to the higher UF content in sunflower meal, certainly, the structural arrangement of lignin may have contributed to greater potential indigestibility.

Interestingly, of the total crude protein (CP) in sunflower meal, $42.22 \%$ is fraction $\mathrm{A}$, being this $29.1 \%$ and $33.7 \%$ higher than the contents of fraction A of cotton cake and castor bean cake, respectively (Table 3). Nutritionally, the fraction A of $\mathrm{CP}$ of the byproducts used in the experimental diets is totally converted into ammonia nitrogen in the rumen, which is used, in ruminal conditions by the fibrolytic bacteria to degrade the fiber and to synthesize protein of microbial origin, when there is availability of energy and carbon skeletons (KOZLOSKI, 2002). On the other hand, numerous alternatives are evaluated to reduce the protein degradability in the rumen and, therefore, to allow better availability of amino acids for intestinal digestion (SANTOS et al., 2004).

Table 3. Ruminal degradability of crude protein of oilseed byproducts.

\begin{tabular}{lccccc}
\hline \multicolumn{1}{c}{ Items (\%) } & \multicolumn{3}{c}{ Byproducts } & \multirow{2}{*}{ SEM } & P-value \\
\cline { 2 - 4 } & $\begin{array}{c}\text { Sunflower } \\
\text { meal }\end{array}$ & Cotton cake & $\begin{array}{c}\text { Castor bean } \\
\text { cake }\end{array}$ & & $<0.01$ \\
\hline Fraction A & $42.22 \mathrm{a}$ & $32.70 \mathrm{~b}$ & $31.58 \mathrm{~b}$ & 0.79 & $<0.01$ \\
Fraction B & $51.14 \mathrm{c}$ & $60.40 \mathrm{~b}$ & $65.32 \mathrm{a}$ & 0.72 & $<0.01$ \\
Degradation Rate c, \%/h & $0.173 \mathrm{a}$ & $0.056 \mathrm{~b}$ & $0.053 \mathrm{c}$ & 0.01 & $<0.01$ \\
Potential Degradability & $93.36 \mathrm{~b}$ & $93.11 \mathrm{~b}$ & $96.90 \mathrm{a}$ & 0.19 & $<0.01$ \\
Potential Degradability, 2\% & $88.03 \mathrm{a}$ & $77.18 \mathrm{~b}$ & $78.86 \mathrm{~b}$ & 0.15 & $<0.01$ \\
Potential Degradability, 5\% & $81.83 \mathrm{a}$ & $64.58 \mathrm{~b}$ & $65.02 \mathrm{~b}$ & 0.20 & $<0.01$ \\
Potential Degradability, 8\% & $77.12 \mathrm{a}$ & $57.54 \mathrm{~b}$ & $57.45 \mathrm{~b}$ & 0.23 & $<0.01$ \\
Undegradable fraction & $6.63 \mathrm{a}$ & $6.88 \mathrm{a}$ & $3.09 \mathrm{~b}$ & 0.19 & \\
\hline
\end{tabular}

Means followed by different letters, in the same row, are significantly different by Tukey's test $(\mathrm{P}<0.05)$. SEM - Standard Error of the Mean. P - Probability.

According to Fortaleza et al. (2009), foods with high rumen degradable protein content (Fraction A) should be balanced with other protein sources with high rumen undegradable protein in diets for high production animals that require higher amounts of protein to be digested in the small intestine. For the 
PD of CP, the highest mean was verified in castor bean cake, however, with a low ED in relation to sunflower meal $(81.83 \%, 5 \%$ rate of passage). This is because most $\mathrm{CP}$ of castor bean cake and cotton cake was adhered to the cell wall with slow ruminal degradation, as can be observed with the values of fraction B of these byproducts that were $27.7 \%$ and $18.10 \%$ higher than the sunflower meal $(51.14 \%$ average), respectively. According to Aguiar et al. (2015), 0.42\% DM of sunflower meal and castor bean meal is represented by the neutral detergent insoluble nitrogen corroborating the results found in this study. Goes et al. (2011) reported values of
PD and ED of CP of soybean meal in the order of 98.97\% and $52.83 \%$. The sunflower meal presented higher $\operatorname{ED}(k=5 \% /$ hour $)$ than soybean meal. For the insoluble protein, represented by the UF of protein, there was variation between the treatments, with the highest mean values in sunflower meal and cotton cake, $6.75 \%$.

On the ruminal degradation of NDF of the byproducts, the lowest mean values for fraction Bp (standardized fraction B) were observed in sunflower meal and castor bean cake, respectively ( $<<0.01$; Table 4).

Table 4. Ruminal degradability of neutral detergent fiber of oilseed byproducts.

\begin{tabular}{lccccc}
\hline \multirow{2}{*}{\multicolumn{1}{c}{ Items (\%) }} & \multicolumn{3}{c}{ Byproducts } & \multirow{2}{*}{ SEM } & P-value \\
\cline { 2 - 4 } & $\begin{array}{c}\text { Sunflower } \\
\text { meal }\end{array}$ & Cotton cake & $\begin{array}{c}\text { Castor bean } \\
\text { cake }\end{array}$ & & $<0.01$ \\
\hline Fraction Bp & $34.40 \mathrm{c}$ & $63.44 \mathrm{a}$ & $39.40 \mathrm{~b}$ & 0.70 & $<0.01$ \\
Degradation Rate c, \%/h & $0.136 \mathrm{a}$ & $0.020 \mathrm{c}$ & $0.080 \mathrm{~b}$ & 0.01 & $<0.01$ \\
Effective Degradability, 2\% & $30.04 \mathrm{~b}$ & $33.01 \mathrm{a}$ & $31.39 \mathrm{~b}$ & 0.32 & $<0.01$ \\
Effective Degradability, 5\% & $25.25 \mathrm{a}$ & $19.22 \mathrm{~b}$ & $24.07 \mathrm{~b}$ & 0.44 & $<0.01$ \\
Effective Degradability, 8\% & $21.78 \mathrm{a}$ & $13.56 \mathrm{c}$ & $19.53 \mathrm{~b}$ & 0.45 & $<0.01$ \\
Fraction Ip & $65.60 \mathrm{a}$ & $36.55 \mathrm{c}$ & $60.59 \mathrm{~b}$ & 0.70 & $<$ \\
\hline
\end{tabular}

Means followed by different letters, in the same row, are significantly different by Tukey's test $(\mathrm{P}<0.05)$. Bp - Insoluble fraction, but potentially degradable standardized. Ip - Standardized indigestible fraction. SEM - Standard Error of the Mean. P - Probability.

However, it was observed that the degradation rate of fraction $B$ (c) of NDF in sunflower meal was $580 \%$ and $70 \%$ higher than the cotton cake and castor bean cake, respectively. The higher content of ether extract present in the cotton cake compared to the other byproducts may have contributed to lower adhesion of fibrolytic bacteria to the substrate particles, which reduced the degradation rate of the insoluble fraction and consequently decreased the ED of NDF (KOZLOSKI, 2002). In sunflower meal, higher ED of NDF was observed in the 5\% and $8 \%$ rates of passage, as proposed by AFRC (1993) in relation to the other byproducts. As lignin is present in the cell wall of plants, high content of standardized indigestible fraction (Ip) of NDF of the byproducts were observed, with the highest mean value observed in sunflower meal (65.6\%) in relation to the other byproducts. The cotton cake showed a value of Ip 39.7\% lower than the castor bean cake $(60.59 \%)$. Fortaleza et al. (2009) evaluated the potential degradability of NDF of cottonseed and soybean meal and observed values of $55.42 \%$ and $83.89 \%$, respectively. These results allow to infer the potential of the cotton cake for ruminant nutrition. Nevertheless, even with high indigestible fraction observed in sunflower meal, the ED of NDF of this food was higher in relation to cotton cake and castor bean cake because of the higher degradation rate of the potentially rumen degradable fraction present in sunflower meal. All the three byproducts used present potential to be used in ruminant nutrition. However, by analyzing in 
a multifactorial way, sunflower meal is nutritionally similar to soybean meal, indicating the possibility of soybean meal replacement in ruminant diets.

\section{Conclusion}

All byproducts evaluated have a potential use in ruminant feeding. However, the sunflower meal had better values of ruminal parameters of dry matter, crude protein and neutral detergent fiber in relation to the other byproducts.

\section{Acknowledgements}

The authors thank the National Council for Scientific and Technological Development (CNPq). This study was financed in part by the Coordination for the Improvement of Higher Education Personnel - Brazil - Finance Code 001.

\section{References}

ABDAllA, A. L.; SIlVA FILHO, J. C.; GODOI, A. R.; CARMO, C. A.; EDUARDO, J. L. P. Utilização de subprodutos da indústria de biodiesel na alimentação de ruminantes. Revista Brasileira de Zootecnia, Viçosa, MG, v. 37, n. 37, p. 260-258, 2008. DOI: 10.1590/S151635982008001300030

AGRICULTURALANDFOOD RESEARCH COUNCIL - AFRC. Energy and protein requirements of ruminants. Walligford: CAB International, 1993.

AGUIAR, A. C. R.; ROCHA JÚNIOR, V. R.; CALDEIRA, L. A.; ALMEIDA FILHO, S. H. C.; RUAS, J. R. M.; SOUZA, V. M.; COSTA, M. D.; PIRES, D. A. A. Composição do leite de vacas alimentadas com diferentes fontes de compostos nitrogenados. Revista Brasileira de Saúde Produção Animal, Salvador, v. 16, n. 3, p. 591605, 2015. DOI: 10.1590/S1519-99402015000300011

ASSOCIATION OF OFFICIAL ANALYTICAL CHEMISTS - AOAC. Official Methods of Analysis of AOAC International. $16^{\text {th }}$ ed. Arlington: Association of Official Analytical Chemists, 1995.

CASALI, A. O.; DETMANN, E.; VALADARES FILHO, S. C.; PEREIRA, J. C.; CUNHA, M.; DETMANN, K. S. C.; PAULINO, M. F. Estimação de teores de componentes fibrosos em alimentos para ruminantes em saco de diferentes tecidos. Revista Brasileira de Zootecnia, Viçosa, MG, v. 38, n. 1, p. 130-138, 2009. DOI: 10.1590/ S1516-35982009000100017

FORTALEZA, A. P. S.; SILVA, L. D. F.; RIBEIRO, E. L. A.; BARBERO, R. P.; MASSARO JÚNIOR, F. L.; SANTOS, A. X.; CASTRO, V. S.; CASTRO, F. A. B. Degradabilidade ruminal in situ dos componentes nutritivos de alguns suplementos concentrados usados na alimentação de bovinos. Semina: Ciências Agrárias, Londrina, v. 30, n. 2, p. 481-496, 2009.

GOERING, H. K.; VAN SOEST, P. J. Forage fiber analysis: Apparatus, reagents, procedures and some applications. Washington: USDA, 1970. 989 p.

GOES, R. H. T. B.; SOUZA, K. A.; NOGUEIRA, K. A. G.; PEREIRA, D. F.; OLIVEIRA, E. R.; BRABES, K. C. S. Degradabilidade ruminal da matéria seca e proteína bruta, e tempo de colonização microbiana de oleaginosas, utilizadas na alimentação de ovinos. Acta Scientiarum. Animal Sciences, Maringá, v. 33, n. 4, p. 373-378, 2011. DOI: $10.4025 /$ actascianimsci.v33i4.11388

JUNG, H. G. Forage lignin and their effects on fiber digestibility. Agronomy Journal, Madison, v. 81, n. 1, p. 33-38, 1989. DOI: 10.2134/agronj1989.0002196200810 0010006x

KOZLOSKI, G. V. Bioquímica dos ruminantes. Santa Maria: Editora UFSM, 2002. 140 p.

MERTENS, D. R.; LOFTEN, J. R. The effects of starch on forage fiber digestion kinetics in vitro. Journal of Dairy Science, Madison, v. 63, n. 9, p. 1437-46, 1980. DOI: $10.3168 /$ jds.S0022-0302(80)83101-8

MIR, Z.; MACLEOD, G. K.; BUCHANAN-SMITH, J. G.; GRIEVE, D. G.; GROVUM, W. L. Methods for protecting soybean and canola proteins from degradation in the rumen. Canadian Journal of Animal Science, Ottawa, v. 64 , n. 4, p. $853-865$, 1984. DOI: $10.4141 /$ cjas84-099

MONÇÃO, F. P.; REIS, S. T.; RIGUEIRA, J. P. S.; SALES, E. C. J.; ALVES, D. D.; AGUIAR, A. C. R.; OLIVEIRA, E. R.; ROCHA JÚNIOR, V. R. Ruminal degradation of dry matter and neutral detergent fiber of banana peel treated with limestone. Semina: Ciências Agrárias, Londrina, v. 37, n. 1, p. 345-356, 2016. DOI: 10.5433/1679-0359.2016v37n1p345

MONÇÃO, F. P.; REIS, S. T.; RIGUEIRA, J. P. S.; SALES, E. C. J.; ANTUNES, A. P. S.; OLIVEIRA, E. R.; CARVAlHO, Z. G. Degradabilidade ruminal da matéria seca e da FND da casca de banana tratada com cal virgem. Revista de Ciências Agrárias, Lisboa, v. 37, n. 2, p. 42-49, 2014. 
MOREIRA, J. F. C.; RODRÍGUEZ, N. M.; FERNANDES, P. C. C.; VELOSO, C. M.; SALIBA, E. O. S.; GONÇALVES, L. C.; BORGES, I.; BORGES, A. L. C. C. Concentrados proteicos para bovinos. 1. Digestibilidade in situ da matéria seca e da proteína bruta. Arquivo Brasileiro de Medicina Veterinária e Zootecnia, Belo Horizonte, v. 55, n. 3, 2003. DOI: 10.1590/S010209352003000300011

NETER, J.; WASSERMAN, W.; KUTNER, M. H. Applied linear statistical models. Regression, analysis of variance, and experimental designs. $2^{\text {th }}$ ed. Athens: Richard D. Irwin, Inc., 1985. 1127 p.

NOCEK, J. E. In situ and others methods to estimate ruminal protein and energy digestibility. Journal of Dairy Science, Madison, v. 71, n. 8, p. 2051-2069, 1988. DOI: 10.3168/jds.S0022-0302(88)79781-7

OLIVEIRA, E. R.; MONÇÃO, F. P.; MOURA, L. V.; GABRIEL, A. M. A.; GÓES, R. H. T. B.; LEMPP, B.; NASCIMENTO, F. A. Valor nutricional de silagem de capim-mombaça com aditivos agroindustriais. Semina: Ciências Agrárias, Londrina, v. 35, n. 3, p. 1543-1556, 2014. DOI: $10.5433 / 1679-0359.2014 v 35 n 3 p 1543$

ØRSKOV, E. R.; MCDONALD, I. The estimation of protein degradability in the rumen from incubation measurements weighted according to rate of passage. Journal Agriculture Science, Cambridge, v. 92, n. 2, p. 499-508, 1979. DOI: $10.1017 /$ S0021859600063048

RIGUEIRA, J. P. S.; MONÇÃO, F. P.; SALES, E. C. J.; REIS, S. T.; BRANT, L. M. S.; CHAMONE, J. M. A.; ROCHA JÚNIOR, V. R.; PIRES, D. A. A. Fermentative profile and nutritional value of elephant grass silage with different levels of crude glycerin. Semina: Ciências Agrárias, Londrina, v. 39, n. 2, p. 833-844, 2018. DOI: $10.5433 / 1679-0359.2018 \mathrm{v} 39 \mathrm{n} 2 \mathrm{p} 833$
ROBERTSON, J. B.; VAN SOEST, P. J. The detergent system of analysis and its application to human foods. In: JAMES, W. P. T.; THEANDER, O. The analysis of dietary fiber in food. New York: Marcel Dekker, 1981. p. 123-158.

STATISTICAL ANALYSIS SYSTEM INSTITUTE SAS Institute. SAS/STAT 9. 2 User's guide. Cary: SAS Institute Inc., 2008.

SANTANA, P. F.; ROCHA JÚNIOR, V. R.; RUAS, J. M. R.; MONÇÃO, F. P.; BORGES, L. A.; RIGUEIRA, J. P. S.; RAMOS, J. C. P.; GOMES, V. M. Feed restriction of F1 Holstein $\times$ Zebu cows in the final third of lactation modifies intake, nutrient digestibility, feeding behavior, and performance. Revista Brasileira de Zootecnia, Viçosa, MG, v. 48, n. 1, p. 1-10, 2019. DOI: 10.1590/ rbz4820180130

SANTOS, G. T.; DAMASCENO, J. C.; JOBIM, C. C.; GONÇALVES, G. D.; CHIQUITELLI NETO, M.; PORTO, P. P.; RIBEIRO, C. R. Efeito dos tratamentos com autoclave e/ou ácido tânico na degradabilidade in situ e na degradabilidade in vitro de grãos de canola. Acta Scientiarum. Animal Sciences, Maringá, v. 26, p. 507512, 2004. DOI: 10.4025/actascianimsci.v26i4.1735

SOUZA, D. D.; SILVA, F. F.; SCHIO, A. R.; PORTO JUNIOR, A. F.; SILVA, R. R.; SANTIAGO, B. M.; RODRIGUES, E. S. O.; ABREU, A. C.; PACHECO, C. C.; MURICY, J. F. Feeding behavior of dairy cows fed different levels of castor meal in the diet. Semina: Ciências Agrárias, Londrina, v. 37, n. 4, p. 2355-2364, 2015. DOI: $10.5433 / 1679-0359.2016 v 37 n 4 S u p 11$ p2355

VAN SOEST, P. J. Nutritional ecology of the ruminant. $2^{\text {th }}$ ed. Ithaca: Comstock, 1994. $476 \mathrm{p}$.

WALDO, D. R.; SMITH, L. W.; COX, E. L. Model of cellulose disappearance from the rumen. Journal of Dairy Science, Madison, v. 55, n. 1, p. 125-129, 1972. DOI: $10.3168 /$ jds.S0022-0302(72)85442-0 
